\title{
The impact of concentration and administration time on the radiomodulating properties of undecylprodigiosin in vitro
}

\author{
Sandra Petrović ${ }^{1}$, Vesna Vasić ${ }^{1}$, Tatjana Mitrovićc ${ }^{3}$, Saša Lazović ${ }^{2}$, and Andreja Leskovac ${ }^{1}$ \\ Vinča Institute of Nuclear Sciences ${ }^{1}$, Institute of Physics Belgrade ${ }^{2}$, University of Belgrade, Institute for Development \\ of Water Resources "Jaroslav Černi", Belgrade, Serbia
}

[Received in October 2016; Similarity Check in October 2016; Accepted in January 2017]

\begin{abstract}
Undecylprodigiosin pigment (UPP) is reported to display cytotoxic activity towards various types of tumours. Nevertheless, its efficacy in modifying the cellular response to ionising radiation is still unknown. In this study, the radiomodulating effects of UPP were investigated. The effects of UPP were assessed in vitro by treating cultures of human peripheral blood with UPP and ionising radiation using two treatment regimens, the UPP pre-irradiation treatment and UPP post-irradiation treatment. The activity of UPP was investigated evaluating its effects on the radiation-induced micronuclei formation, cell proliferation, and induction of apoptosis. The redox modulating effects of UPP were examined measuring the catalase activity and the level of malondialdehyde, as a measure of oxidative stress. The results showed that UPP effects on cellular response to ionising radiation depend on its concentration and the timing of its administration. At low concentration, the UPP displayed radioprotective effects in $\gamma$-irradiated human lymphocytes while at higher concentrations, it acted as a radiosensitiser enhancing either mitotic catastrophe or apoptosis depending on the treatment regimen. The UPP modified redox processes in cells, particularly when it was employed prior to $\gamma$-irradiation. Our data highlight the importance of further research of the potential of UPP to sensitize tumour cells to radiation therapy by inhibiting pathways that lead to treatment resistance.
\end{abstract}

KEY WORDS: apoptosis; mitotic catastrophe; oxidative stress; radiosensitisation; undecylprodigiosin

The main therapeutic modalities to treat cancer are surgery, radiotherapy, and chemotherapy. Radiotherapy is one of the most effective forms of cancer treatment. However, ionising radiation (IR) used for the elimination of malignant tumours induces persistent DNA double-strand breaks (DSBs) leading to the permanent cell growth arrest, apoptosis, necrosis, or mitotic catastrophe (1). The major difficulties encountered during the treatment of cancer are tumour resistance to therapy and therapy-associated normal tissue toxicity (2). Alternative approaches to enhancing the efficacy of radiotherapy and minimising its harmful side effects focus on a combined treatment with anticancer drug and radiation (2). The potential radiotherapeutic agents are commonly categorised as (i) radioprotectors, which reduce normal tissue toxicity, thus, minimising the side effects of radiotherapy, and (ii) radiosensitisers, which enhance the radiosensitivity of tumour cells, thereby minimising the radiation dosage and damage to surrounding normal tissues $(3,4)$. Radiosensitisation of tumour cells by different agents is mainly achieved by enhancement of radiation-induced DNA damage in tumour cells compared to surrounding tissues, inhibition of DNA synthesis and cell growth, and

Correspondence to: Dr Andreja Leskovac, Vinča Institute of Nuclear Sciences, University of Belgrade, M. Petrovića Alasa 12-14, 11001 Belgrade, Serbia, e-mail: andreja@vinca.rs enhancement of radiation-induced apoptosis $(2,5)$. Another approach is to modulate reduction/oxidation reactions within tumour cells (4).

In the last few decades, a wide variety of naturally occurring compounds have been tested in order to identify effective radiosensitisers that could enhance the sensitivity of cancer to the effects of IR and improve the cancer patients' survival rate (6-8). Plant-derived anticancer drugs continue to play a significant role in the development of new therapeutics aimed at modifying the radiobiological response of cells. Plant compounds such as etoposide, pactitaxel, and Vinca alkaloids have been recognised as radiosensitisers with low toxicity and high effectiveness whose synergism with radiation therapy increases the likelihood of cancer treatments (9). However, besides plants, microorganisms represent a profuse source of diverse bioactive metabolites with anticancer and possible radiomodulating activities.

Prodigiosins (PGs), produced as secondary metabolites by many terrestrial and marine bacterial strains such as the species of Serratia (10) and Streptomyces $(11,12)$, are a family of natural red pigments that are reported to possess antimicrobial, immunosuppressive, and cytotoxic activities (13-15). It has been reported that PGs mainly target cancer cells (hematopoietic, gastrointestinal, breast, and lung 
cancer) with little or no effects on normal cells (16-18) Numerous studies indicated that PGs displayed selective cytotoxicity against cancer cells, anti-metastatic activity, and p53-independent proapoptotic effects, which points to their potency as anticancer agents $(16,19)$.

Recent studies put a PG family member, undecylprodigiosin pigment (UPP), in the focus of anticancer investigation based on its proapoptotic potency demonstrated in various types of tumours (20-23). It has been suggested that UPP inhibits cell proliferation by inducing G2/M phase arrest and apoptosis of cancer cells. The tumoricidal action of UPP alone and UPP conjugated to gold nanoparticles was observed in melanoma, lung, breast, and colon cancer cells, enabling the platform for further development of efficient anticancer drugs suitable for clinical application (22). On the other side, it has been shown that UPP provides protection against oxidative stress by delaying the lipid peroxidation process (24) and displaying the antioxidant properties and mitochondrial function improvement (25). Similar findings were obtained in our previous investigation showing that treatment of human lymphocytes with low UPP concentrations $\left(0.1 \mu \mathrm{g} \mathrm{mL}^{-1}\right)$ significantly reduced DNA damages and maintained the redox homeostasis of cells, indicating its cytoprotective nature. At moderate concentrations $\left(1 \mu \mathrm{g} \mathrm{mL}^{-1}\right)$, UPP displayed effects similar to that of the untreated control, while the highest applied concentration (5 $\mu \mathrm{g} \mathrm{mL}^{-1}$ ) was genotoxic (unpublished data). The protective effects of UPP against UV irradiation were described previously (26).

As far as we know, the effect of UPP as a modifier of cellular response to ionising radiation is still unknown. Therefore, in this study, we investigated potential radioprotective/radiosensitising effects of UPP in $\gamma$-irradiated human peripheral blood cells using different combined treatment regimens with UPP and IR. The influence of UPP on radiation-induced apoptosis, micronuclei (MNi) induction, and oxidative stress alterations was investigated.

\section{MATERIALS AND METHODS}

\section{Undecylprodigiosin pigment (UPP) preparation}

Undecylprodigiosin (UP) pigment was synthesised in a shake flask culture of Streptomyces sp. JS520 using mannitol-soy-yeast medium supplemented with methyloleate $(0.2 \%, \mathrm{v} / \mathrm{v})$ for six days at $30{ }^{\circ} \mathrm{C}$ and recovered and purified by column chromatography. The quality of the purified UP was analysed by liquid chromatography coupled to mass spectroscopy (LC-MS) as described previously (24).

\section{Cell cultures and treatments}

Blood sample was obtained from a healthy, nonsmoking, 30-year-old male volunteer donor in accordance with current Health and Ethical Regulations in Serbia (27). Aliquots of heparinised whole blood $(0.5 \mathrm{~mL})$ were first added to culture tubes containing $4.5 \mathrm{~mL}$ of RPMI-1640 medium supplemented with $15 \%$ calf serum (InvitrogenGibco, Paisley, UK) and were then treated with an increasing concentration of UPP (final concentrations $0.1 \mu \mathrm{g} \mathrm{mL}^{-1}, 1 \mu \mathrm{g} \mathrm{mL}^{-1}$, and $5 \mu \mathrm{g} \mathrm{mL}^{-1}$ ).

The UPP effects were studied employing the experimental set up used in the study of Shukla et al. (28). For each UPP concentration, two treatment regimens were applied: pre-treatment - UPP was added to cell cultures and then exposed to $\gamma$-irradiation, and post-treatment - cell cultures were treated with $\gamma$-irradiation and then exposed to UPP treatment. $\gamma$-irradiated cultures not treated with UPP served as control.

For pre-treatment, UPP was added to cell cultures and incubated at $37^{\circ} \mathrm{C}$ for one hour. Cultures were subsequently exposed to $2 \mathrm{~Gy}$ of ${ }^{60} \mathrm{Co} \gamma$-radiation, at a dose rate of $0.45 \mathrm{~Gy} \mathrm{~min}^{-1}$. After irradiation, UPP was washed off by centrifugation and cultures were reconstituted by adding $4.5 \mathrm{~mL}$ of RPMI-1640 medium supplemented with $15 \%$ calf serum and $2 \%$ phytohemagglutinin (Invitrogen-Gibco, Paisley, UK). They were then incubated at $37^{\circ} \mathrm{C}$ for $72 \mathrm{~h}$.

For post-treatment, cell cultures were exposed to $\gamma$-irradiation as described above. Immediately after irradiation, phytohemagglutinin and UPP were added to the cultures, which were then incubated for $72 \mathrm{~h}$.

The adequate number of blood cultures was established to enable examinations of the MNi frequency, cytokinesisblock proliferation index (CBPI), catalase activity (CAT), and malondialdehyde (MDA) level.

For the apoptosis (AP) assay, blood aliquots of $0.5 \mathrm{~mL}$ were incubated in a RPMI-1640 medium (Invitrogen-Gibco, Paisley, UK) supplemented with $15 \%$ calf serum (Invitrogen-Gibco, Paisley, UK) for $24 \mathrm{~h}$. The treatments with UPP and $\gamma$-irradiation were performed as described above.

For each analysis performed, three independent experiments were carried out. The obtained data were pooled and results were expressed as the mean and standard deviation (SD) of the mean.

\section{Micronucleus assay}

Radiosensitivity was assessed using the cytokinesis block method of Fenech (29). For MN preparation, Cytochalasin B (Sigma-Aldrich, St. Louis, MO, USA) at a final concentration of $4 \mu \mathrm{g} \mathrm{mL}^{-1}$ was added to each culture $44 \mathrm{~h}$ after incubation in order to inhibit cytokinesis. Lymphocyte cultures were incubated for further $28 \mathrm{~h}$. Cells were collected by centrifugation and treated with a hypotonic solution $(0.56 \% \mathrm{KCl}+0.90 \% \mathrm{NaCl}$, mixed in equal volumes) at $37{ }^{\circ} \mathrm{C}$. Cell suspension was fixed in 
methanol/acetic acid (3:1), washed three times with a fixative, and dropped onto clean slides. Slides were air-dried and stained in alkaline Giemsa. For each sample, at least 1000 binucleated $(\mathrm{BN})$ cells were scored and $\mathrm{MNi}$ were recorded using an Optech microscope (Munich, Germany) with $400 x$ or $1000 x$ magnification.

\section{Cytokinesis-block proliferation index}

The ability of cells to proliferate in vitro was evaluated by counting the number of cells with one to four nuclei on the same slides. The results of these analyses are presented as a cytokinesis-block proliferation index. CBPI was calculated according to the method of Surrales at al. (30) as follows: $\mathrm{CBPI}=[\mathrm{MI}+2 \mathrm{MII}+3(\mathrm{MIII}+\mathrm{MIV})] / \mathrm{N}$, where MI-MIV represents the number of cells with one to four nuclei, respectively, and $\mathrm{N}$ is the number of cells scored.

\section{Apoptosis of leukocytes}

After $24 \mathrm{~h}$ of incubation, cells were gently washed with physiological saline $(0.9 \% \mathrm{NaCl})$ at $37{ }^{\circ} \mathrm{C}$, and fixed in methanol/acetic acid (3:1). Afterwards, the pellet was fixed in $96 \%$ ethanol and stored at $+4{ }^{\circ} \mathrm{C}$. Samples were incubated at room temperature for $10-15 \mathrm{~min}$ in incubation phosphate buffer. Propidium iodide (PI, Sigma-Aldrich) and Ribonuclease A (RNase A, Sigma-Aldrich) were added 5 min prior to the flow cytometry analysis.

Apoptosis was assessed by flow cytometric (Partec, Germany) identification of cells displaying apoptosisassociated DNA condensation. DNA content was assessed by measuring the UV fluorescence of propidium iodide stained DNA. Apoptotic population was calculated using the Flow Max software (Partec, Germany).

\section{Blood culture preparation}

After $72 \mathrm{~h}$ of incubation, blood cultures were separated on a Lymphoprep (Lymphocyte separation medium, PAA Laboratories $\mathrm{GmbH}$, Pasching, Austria); lymphocytes were collected by centrifugation, washed in a physiological saline, and frozen at $-20{ }^{\circ} \mathrm{C}$ for the TBA assay, while erythrocytes were haemolysed in ice cold deionised water and frozen at $-20^{\circ} \mathrm{C}$ for subsequent analyses of the catalase activity.

\section{Assay of the catalase activity}

The catalase activity was measured using the method of Aebi (31) with minor modifications by following the catalytic reduction of hydrogen peroxide. The decomposition of the substrate $\mathrm{H}_{2} \mathrm{O}_{2}$ was measured using a Perkin Elmer Lambda 25 Spectrophotometer (Perkin Elmer Instruments, Norwalk, CT, USA) at $240 \mathrm{~nm}$. The activity was expressed as $\mathrm{K}$ - rate constant of the first-order reaction per minute per mg of $\mathrm{Hb}$. Haemoglobin concentration was determined using the Drabkin's method.

\section{Thiobarbituric acid (TBA) assay}

A thawed lymphocyte suspension was treated with thiobarbituric acid, and used to determine malondialdehyde levels, spectrophotometrically at $532 \mathrm{~nm}$ (32). Values were expressed as nmol TBA-reactive substance (MDA equivalent) $/ \mathrm{mg}$ protein, using a standard curve of 1,1,3,3-tetramethoxypropane. Protein concentration was determined according to the method of Lowry et al. (33).

\section{Statistics}

Statistical analysis was carried out using the Statistica 8 and OriginPro 8.5.1 software packages for Microsoft Windows. Statistical analysis was done using the MannWhitney U test. $P$ values of less than 0.05 were considered to be significant.

\section{RESULTS}

The radiomodulating effects of UPP were assessed in vitro by treating human peripheral blood cultures with UPP and IR using two treatment regimens: UPP was added to the cultures one hour prior to $\gamma$-irradiation as pre-treatment and immediately after $\gamma$-irradiation as post-treatment. The activity of UPP was investigated evaluating its effects on the radiation-induced $\mathrm{MNi}$ formation, cell proliferation, and induction of apoptosis. The redox modulating effects of UPP were examined measuring the catalase activity and the level of malondialdehyde, the lipid peroxidation product, as markers of oxidative stress.

\section{Combined treatment with IR and UPP - the UPP pre-treatment regimen}

As shown in Table 1, the UPP pre-treatment, at low concentration, induced a significant reduction of the $\mathrm{MNi}$ frequency (by $13 \%$ ) compared to control (irradiated sample not treated with UPP) $(\mathrm{p}<0.05)$. At higher applied UPP concentrations, no considerable differences in the $\mathrm{MNi}$ frequency compared to control were observed. The proliferation potential of cells was almost unchanged up to the highest applied concentration when significant suppression of cell proliferation was found $(p<0.05)$. As shown in Figure 1, the percentage of apoptotic cells was significantly higher (by approximately $50 \%$ ) than that in control $(p<0.01)$, irrespective of the UPP concentration.

Considering the redox modulating activities of UPP, in cell cultures that were pre-treated with the lowest UPP concentration, a significant decrease in the MDA level (by $32 \%)$ was observed $(\mathrm{p}<0.05)$, while the subsequent increase in UPP concentrations enhanced MDA level $(p<0.05)$, potentiating hence the effects of IR (Figure 2a). As shown in Figure 2b, the catalase activity slightly increased in a dose-dependent manner reaching significant enhancement (by $36 \%$ ) at the highest UPP concentration applied $(\mathrm{p}<0.05)$. 
Table 1 Frequency of micronuclei and proliferation potential of cells (mean $\pm S D$ ) in human lymphocytes treated with UPP and $\gamma$-irradiation (UPP pre-irradiation treatment and UPP post-irradiation treatment)

\begin{tabular}{lccc}
\hline & & $\begin{array}{c}\text { Frequency of micronuclei } \\
(\mathbf{M N})\end{array}$ & $\begin{array}{c}\text { Proliferation potential } \\
\text { (CBPI) }\end{array}$ \\
\hline Unirradiated Control & & $10.56 \pm 1.22$ & $1.82 \pm 0.02$ \\
\hline$\gamma$-irradiated Control & & $215.87 \pm 8.46$ & $1.51 \pm 0.04$ \\
\hline & UPP concentration & $1.53 \pm 0.01$ \\
\hline \multirow{2}{*}{$\begin{array}{l}\text { UPP } \\
\text { pre-irradiation treatment }\end{array}$} & $0.1 \mu \mathrm{g} \mathrm{ml}^{-1}$ & $189.04 \pm 9.41^{*}$ & $1.48 \pm 0.02$ \\
\cline { 2 - 4 } & $1 \mu \mathrm{g} \mathrm{ml}^{-1}$ & $203.33 \pm 4.55$ & $1.40 \pm 0.03 *$ \\
\hline \multirow{2}{*}{$\begin{array}{l}\text { UPP } \\
\text { post-irradiation treatment }\end{array}$} & $5 \mu \mathrm{g} \mathrm{ml}^{-1}$ & $215.43 \pm 8.38$ & $1.48 \pm 0.01$ \\
\cline { 2 - 4 } & $0.1 \mu \mathrm{g} \mathrm{ml}^{-1}$ & $228.30 \pm 9.30$ & $1.41 \pm 0.02 *$ \\
\cline { 2 - 4 } & $1 \mu \mathrm{g} \mathrm{ml}^{-1}$ & $231.27 \pm 6.81^{*}$ & $1.38 \pm 0.02^{*}$ \\
\hline
\end{tabular}

*Comparison with $\gamma$-irradiated control, $p<0.05$

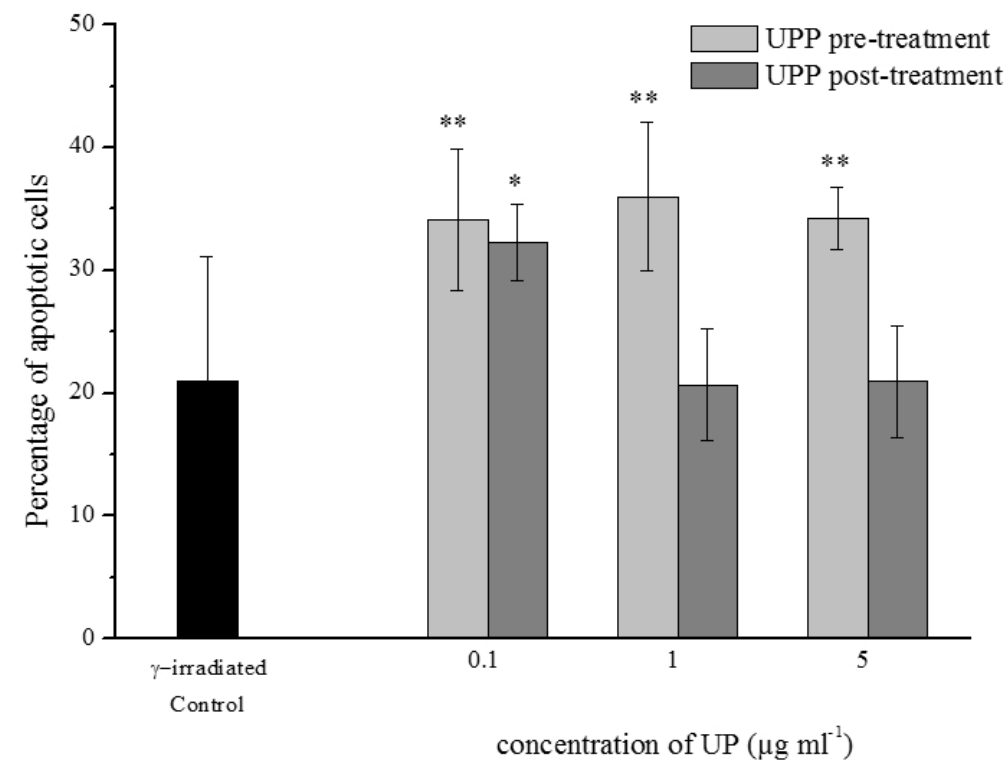

Figure 1 Apoptosis of leukocytes in a combined treatment with IR and UPP (mean $\pm S D$ ); Comparison with $\gamma$-irradiated control, ${ }^{*} p<0.05, * * p<0.01$

a

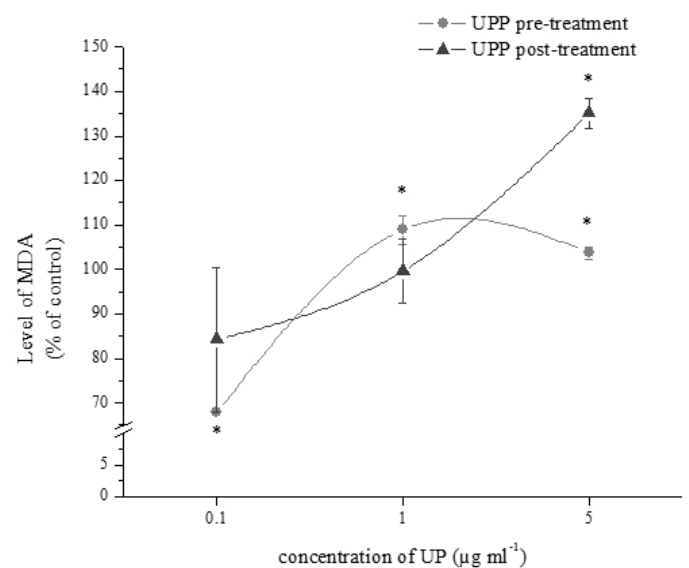

b

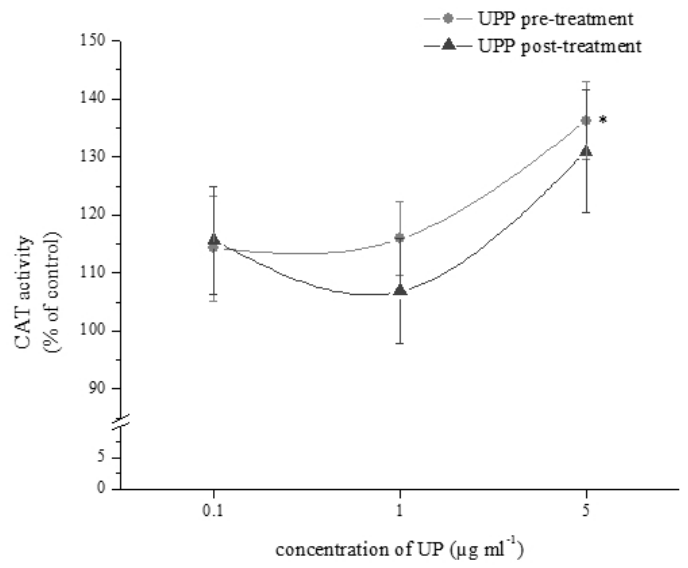

Figure 2 (a) Level of malondialdehyde and (b) Catalase activity in cell cultures treated with UPP and $\gamma$-irradiation (UPP pre-irradiation treatment and UPP post-irradiation treatment), expressed as a percentage of $\gamma$-irradiated control set to $100 \%$ (mean $\pm S D$ ); Comparison with $\gamma$-irradiated control, ${ }^{*} p<0.05$ 
Combined treatment with IR and UPP - the UPP post-treatment regimen

The UPP post-treatment resulted in significant enhancement of radiation-induced $\mathrm{MN}$ (by $15 \%$ ) and reduction of cell proliferation in a concentration dependent manner $(\mathrm{p}<0.05)$ (Table 1).

The percentage of apoptotic cells was significantly enhanced (by approximately $50 \%$ ) compared to control only at the lowest applied UPP concentration $(\mathrm{p}<0.05)$, while a further increase in UPP concentrations decreased apoptosis to control level (Figure 1).

As shown in Figure 2a, the UPP post-treatment caused no significant changes in the MDA level except for the highest UPP concentration, which enhanced radiationinduced lipid peroxidation by $35 \%(\mathrm{p}<0.05)$.

The UPP post-treatment caused mild, insignificant enhancement of the catalase activity (Figure 2b). Schematic representation of the treatment of human peripheral blood lymphocytes with UPP and $\gamma$-irradiation is given in Figure 3.

\section{DISCUSSION}

Different classes of natural compounds have been investigated for their potencies to augment the therapeutic index of radiotherapy (1). Although PGs have been found to display anticancer activities, their efficacy in modifying cellular response to IR has not been investigated so far. In this study, we examined the influence of UPP on different end-points of radiation damage. Results of the study clearly indicate that UPP radiomodulating effects depend on its concentration and treatment regimens.
IR is known to cause direct DNA damage and indirect DNA damage is caused by free radicals derived from the ionisation or excitation of the water component of cells (34). Reactive oxygen species (ROS) generated upon irradiation induce DNA strand breaks and structural and functional alterations of biomolecules (35). Some ROS i.e. $\mathrm{HO}_{2}{ }^{-}$and $\mathrm{H}_{2} \mathrm{O}_{2}$ can pass through cell membranes, which results in important changes in cellular functions (36).

Acting on cells before radiation exposure, UPP displayed significant proapoptotic effects enhancing the radiation-induced apoptosis independently of the concentration applied. This result is in accordance with the previously reported propensity of PGs to induce apoptosis. It has been shown that prodigiosins modulate the expression of Bcl-2 family proteins, IAP proteins, and death ligand/ receptors involving both mitochondrial and death-receptor apoptotic pathways (19). The influence of UPP on radiationinduced MNi formation appeared to be concentration dependent. Specifically, the low UPP concentration attenuated the radiation-induced MNi frequency while the subsequent increase of UPP concentrations kept the level of MNi similar to that of control. On the other hand, the UPP post-treatment induced enhanced radiation-induced $\mathrm{MNi}$ and suppressed cell proliferation in a concentration dependant manner. A dose-dependent increase in the frequency of MNi in the lymphocytes treated with UPP was also observed in our previous study (unpublished data). These results suggest that UPP added to cell cultures after irradiation displayed cytostatic effects and promoted mitotic catastrophe, a type of cell death that results from abnormal mitosis and leads to the formation of cells with multiple $\mathrm{MNi}$ (37). In this treatment regimen, the observed decrease in radiation-induced apoptosis is compensated by an

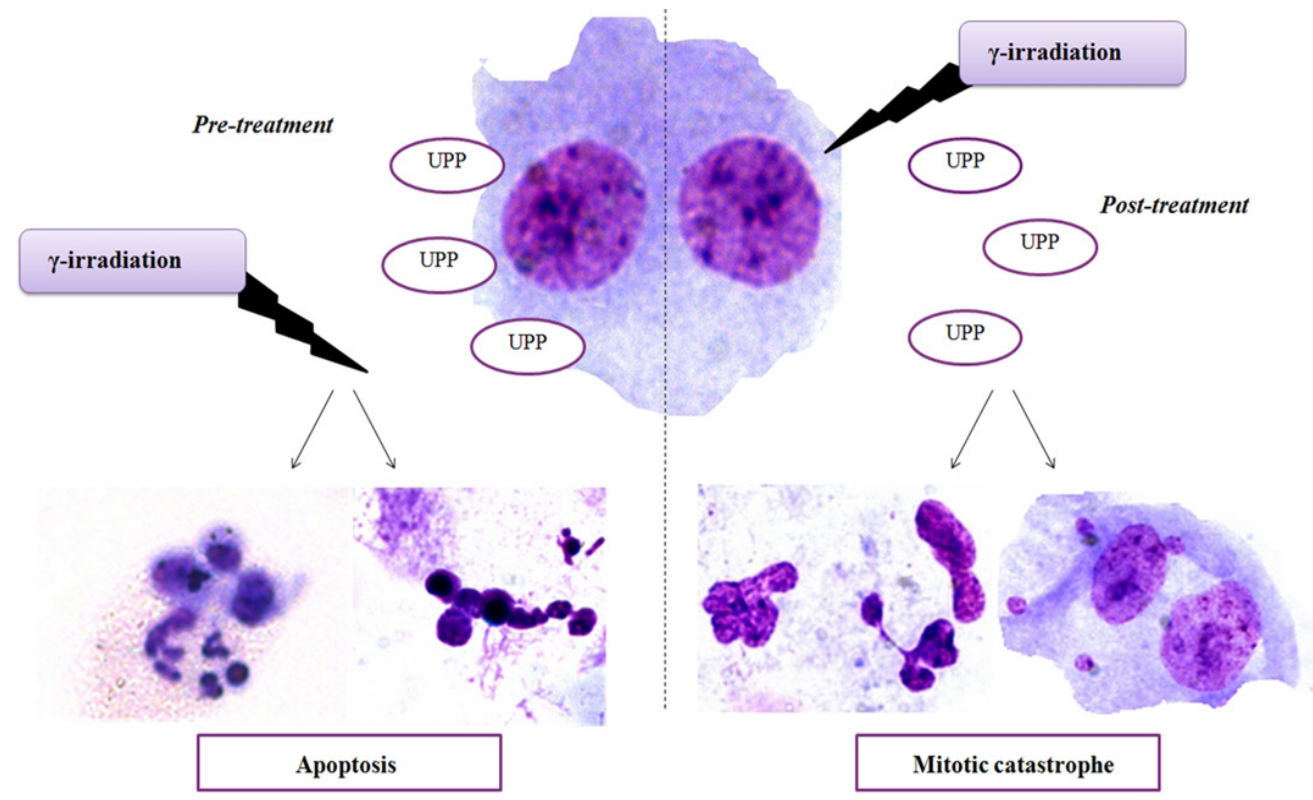

Figure 3 Schematic representation of the treatment of human peripheral blood lymphocytes with UPP and $\gamma$-irradiation. Left panel: Treatment with UPP prior to $\gamma$-irradiation enhanced radiation-induced apoptosis; Right panel: The UPP post-irradiation treatment enhanced radiation-induced mitotic catastrophe 
increase in the fractions of cells that die through the process of mitotic catastrophe. Mitotic catastrophe represents the main form of cell death induced by IR (38). Thus, in a posttreatment regimen, UPP contributed to the inappropriate entry of cells into mitosis possibly via suppression of multiple central checkpoint proteins or disturbance of the mitotic spindle formation.

The effect of UPP on radiation-induced lipid peroxidation is mainly observed in the UPP pre-treatment; the experimental data showed that high concentration of UPP displayed pro-oxidant effects, while at low concentration UPP possessed antioxidant properties and acted as a scavenger of highly reactive free radicals generated upon irradiation. The attenuation of radiation-induced injury was also seen through the reduction of IR-induced MNi as described above. However, UPP at the same concentration proved to be ineffective as antioxidant if administered at the post-irradiation stage. Augmented levels of intrinsic oxidative stress have been found in a variety of tumours, possibly due to more active metabolism, mitochondrial mutation, cytokines, and inflammation (39). Therefore, modulating the redox status of cancer cells might be critical for their survival (40). In that way, UPP as the IR-induced oxidative stress enhancer may sensitise cancer cells to undergo apoptotic death, which was the scenario observed in cell cultures pre-treated with UPP. It can be assumed that UPP promotes the fixation of IR-induced free radicals and prevents the repair of cellular radiation damage. In addition, the highest UPP concentration added to cells prior to gamma irradiation induced a significant enhancement of the catalase activity. Knowing that many human cancers including melanoma, neuroblastoma, colon carcinoma, and ovarian carcinoma, constitutively generate a high amount of $\mathrm{H}_{2} \mathrm{O}_{2}$ (41), it can be assumed that UPP may induce cell cycle arrest and apoptosis of these cancer cells through the scavenging of $\mathrm{H}_{2} \mathrm{O}_{2}$ by overexpressed catalase. It is worth noting that in a post-treatment regimen, the UPP redox modulating activities were attenuated. Radiation-induced lipid peroxidation was potentiated by UPP only at the highest employed concentration.

\section{CONCLUSION}

Taken together, the results of this study suggest that UPP effects on cellular response to IR vary from mild radioprotection to radiosensitisation depending on its concentration and the timing of its administration, i.e. preor post-irradiation stage. At higher concentrations, the UPP's genotoxic and pro-oxidant behaviour augmented radiation-induced injury and it acted as a radiosensitiser enhancing either mitotic catastrophe or apoptosis depending on the treatment regimen. These findings highlight the importance of further research of UPP effects in cancer cells in terms of its utilisation for sensitising tumour cells to radiation therapy. If proven to be inefficient in killing cancer cells, this kind of exposure and high concentrations of UPP should not be applied. When applied at pre-irradiation stage, UPP, at low concentration, displayed radioprotective effects in gamma-irradiated human lymphocytes reducing $\mathrm{MNi}$ formation and acting as an antioxidant, thus exhibiting potential for further research.

\section{Acknowledgments}

This work has been supported by the Ministry of Education, Science and Technological Development of the Republic of Serbia (Project no. 172023). The authors are thankful to Dr Branka Vasiljević, Dr Jasmina Nikodinović and Dr Lidija Šenerović from the Institute of Molecular Genetics and Genetic Engineering, Belgrade, Serbia, for providing UPP for the research.

\section{REFERENCES}

1. Labay E, Efimova EV, Quarshie BK, Golden DW, Weichselbaum RR, Kron SJ. Ionizing radiation-induced foci persistence screen to discover enhancers of accelerated senescence. Int J High Throughput Screen 2011:2:1-13. doi: 10.2147/IJHTS.S17076

2. Garg AK, Buchholz TA, Aggarwal BB. Chemosensitization and radiosensitization of tumors by plant polyphenols. Antioxid Redox Signal 2005;7:1630-47. doi: 10.1089/ ars.2005.7.1630

3. Hazra B, Ghosh S, Kumar A, Pandey BN. The prospective role of plant products in radiotherapy of cancer: a current overview. Front Pharmacol 2012;2:94. doi: 10.3389/ fphar.2011.00094

4. Rosenberg A, Knox S. Radiation sensitization with redox modulators: a promising approach. Int J Radiat Oncol Biol Phys 2006;64:343-54. doi: 10.1016/j.ijrobp.2005.10.013

5. Papazisis KT, Zambouli D, Kimoundri OT, Papadakis ES, Vala V, Geromichalos GD, Voyatzi S, Markala D, Destouni E, Boutis L, Kortsaris AH. Protein tyrosine kinase inhibitor, genistein, enhances apoptosis and cell cycle arrest in K562 cells treated with gamma-irradiation. Cancer Lett 2000;160:107-13. doi: 10.1016/S0304-3835(00)00569-3

6. Begg AC, Stewart FA, Vens C. Strategies to improve radiotherapy with targeted drugs. Nat Rev Cancer 2011;11:239-53. doi: 10.1038/nrc3007

7. Joksic G, Leskovac A, Petrovic S. Modulation of radiationinduced damage by Serbian natural plant products: implications for radioprotection. In: Arora R, editor. Herbal radiomodulators: applications in medicine, homeland defence and space. Oxfordshire: CAB International; 2008. p. 67-82.

8. Moding EJ, Kastan MB, Kirsch DG. Strategies for optimizing the response of cancer and normal tissues to radiation. Nat Rev Drug Discov 2013;12:526-42. doi: 10.1038/nrd4003

9. Burris HA, $3^{\text {rd }}$, Hurtig J. Radiation recall with anticancer agents. Oncologist 2010;15:1227-37. doi: 10.1634/ theoncologist.2009-0090

10. Thomson NR, Crow MA, McGowan SJ, Cox A, Salmond GP. Biosynthesis of carbapenem antibiotic and prodigiosin pigment in Serratia is under quorum sensing control. Mol Microbiol 2000;36:539-56. doi: 10.1046/j.1365-2958. 2000.01872.x 
11. Hobbs G, Frazer CM, Gardner DCJ, Flett F, Oliver SG. Pigmented antibiotic production by Streptomyces coelicolor A3(2): kinetics and the influence of nutrients. J Gen Microbiol 1990;136:2291-6. doi: 10.1099/00221287-136-11-2291

12. Kawasaki T, Sakurai F, Hayakawa Y. A prodigiosin from the roseophilin producer Streptomyces griseoviridis. J Nat Prod 2008;71:1265-7. doi: 10.1021/np7007494

13. Nakamura A, Magae J, Tsuji RF, Yamasaki M, Nagai K. Suppression of cytotoxic $\mathrm{T}$ cell induction in vivo by prodigiosin 25-C. Transplantation 1989;47:1013-6. doi: 10.1097/00007890-198906000-00019

14. Songia S, Mortellaro A, Taverna S, Fornasiero C, Scheiber EA, Erba E, Colotta F, Mantovani A, Isetta AM, Golay J. Characterization of the new immunosuppressive drug undecylprodigiosin in human lymphocytes: retinoblastoma protein, cyclin-dependent kinase-2, and cyclin-dependent kinase-4 as molecular targets. J Immunol 1997;158:3987-95. PMID: 9103470

15. Tsuji RF, Magae J, Yamashita M, Nagai K, Yamasaki M. Immunomodulating properties of prodigiosin $25-\mathrm{C}$, an antibiotic which preferentially suppresses induction of cytotoxic T cells. J Antibiot (Tokyo) 1992;45:1295-302. PMID: 1399851

16. Pandey R, Chander R, Sainis KB. Prodigiosins as anti cancer agents: living upto their name. Curr Pharm Design 2009;15:732-41. doi: 10.2174/138161209787582192

17. Yamamoto C, Takemoto H, Kuno K, Yamamoto D, Nakai K, Baden T, Kamata K, Hirata H, Watanabe T, Inoue K. Cycloprodigiosin hydrochloride, a $\mathrm{H}+/ \mathrm{Cl}$ - symporter, induces apoptosis in human colon cancer cell lines in vitro. Oncol Rep 2001;8:821-4. PMID: 11410791

18. Yamamoto D, Kiyozuka Y, Uemura Y, Yamamoto C, Takemoto H, Hirata H, Tanaka K, Hioki K, Tsubura A. Cycloprodigiosin hydrochloride, a $\mathrm{H}+/ \mathrm{Cl}$ - symporter, induces apoptosis in human breast cancer cell lines. J Cancer Res Clin Oncol 2000;126:191-7. doi: 10.1007/s004320050032

19. Chang CC, Chen WC, Ho TF, Wu HS, Wei YH. Development of natural anti-tumor drugs by microorganisms. J Biosci Bioeng 2011;111:501-11. doi: 10.1016/j.jbiosc.2010.12.026

20. Ho TF, Ma CJ, Lu CH, Tsai YT, Wei YH, Chang JS, Lai JK, Cheuh PJ, Yeh CT, Tang PC, Tsai Chang J, Ko JL, Liu FS, Yen HE, Chang CC. Undecylprodigiosin selectively induces apoptosis in human breast carcinoma cells independent of p53. Toxicol Appl Pharmacol 2007;225:318-28. doi 10.1016/j.taap.2007.08.007

21. Liu P, Wang YY, Qi X, Gu Q, Geng M, Li J. Undecylprodigiosin induced apoptosis in P388 cancer cells is associated with its binding to ribosome. PLoS One 2013;8:e65381. doi: 10.1371/ journal.pone.0065381

22. Nikodinovic-Runic J, Mojic M, Kang Y, Maksimovic-Ivanic D, Mijatovic S, Vasiljevic B, Stamenkovic VR, Senerovic L. Undecylprodigiosin conjugated monodisperse gold nanoparticles efficiently cause apoptosis in colon cancer cells in vitro. J Mater Chem B. 2014;2:3271-81. doi: 10.1039/ C4TB00300D

23. Stankovic N, Senerovic L, Ilic-Tomic T, Vasiljevic B, Nikodinovic-Runic J. Properties and applications of undecylprodigiosin and other bacterial prodigiosins. Appl Microbiol Biotechnol 2014;98:3841-58. doi: 10.1007/ s00253-014-5590-1

24. Stankovic N, Radulovic V, Petkovic M, Vuckovic I, Jadranin M, Vasiljevic B, Nikodinovic-Runic J. Streptomyces sp.
JS520 produces exceptionally high quantities of undecylprodigiosin with antibacterial, antioxidative, and UV-protective properties. Appl Microbiol Biotechnol 2012;96:1217-31. doi: 10.1007/s00253-012-4237-3

25. Leiros M, Alonso E, Sanchez JA, Rateb ME, Ebel R, Houssen WE, Jaspars M, Alfonso A, Botana LM. Mitigation of ROS insults by Streptomyces secondary metabolites in primary cortical neurons. ACS Chem Neurosci 2014;5:71-80. doi: $10.1021 / \mathrm{cn} 4001878$

26. Boric M, Danevcic T, Stopar D. Prodigiosin from Vibrio sp. DSM 14379; a new UV-protective pigment. Microb Ecol 2011;62:528-36. doi: 10.1007/s00248-011-9857-0

27. Law on health care. Official Gazette of the Republic of Serbia. Parliament of the Republic of Serbia. 2005. 107:112-161.

28. Shukla S, Anjaria K, Bhat N, Shirsath K, Sreedevi B. Effect of caffeine on radiation induced micronuclei in human lymphocytes. Radiat Protect Environ 2010;33:195-8 [displayed 11 January 2017]. Available at http://www.rpe. org.in/article.asp?issn=0972-0464; year=2010; volume=33;i ssue $=4$; spage $=195$; epage $=198$; aulast $=$ Shukla

29. Fenech M. The cytokinesis-block micronucleus technique: a detailed description of the method and its application to genotoxicity studies in human populations. Mutat Res 1993;285:35-44. doi: 10.1016/0027-5107(93)90049-L

30. Surralles J, Xamena N, Creus A, Marcos R. The suitability of the micronucleus assay in human lymphocytes as a new biomarker of excision repair. Mutat Res 1995;342:43-59. doi: 10.1016/0165-1218(95)90089-6

31. Aebi H. Catalase. In: Bergmeyer HU, editor. Methods of enzymatic analysis. Weinheim: Verlag Chemie; 1974. p. 673-6.

32. Aruoma OI, Halliwell B, Laughton MJ, Quinlan GJ, Gutteridge JM. The mechanism of initiation of lipid peroxidation. Evidence against a requirement for an iron(II)iron(III) complex. Biochem J 1989;258:617-20. doi: 10.1042/ bj2580617

33. Lowry OH, Rosebrough NJ, Farr AL, Randall RJ. Protein measurement with the Folin phenol reagent. J Biol Chem 1951;193:265-75. PMID: 14907713

34. Baskar R, Lee KA, Yeo R, Yeoh KW. Cancer and radiation therapy: current advances and future directions. Int J Med Sci 2012;9:193-9. doi: 10.7150/ijms.3635

35. Halliwell B, Gutteridge J. Free Radicals in Biology and Medicine. 4 ed. Oxford: Oxford University Press; 2007.

36. Azzam EI, Jay-Gerin JP, Pain D. Ionizing radiation-induced metabolic oxidative stress and prolonged cell injury. Cancer Lett 2012;327:48-60. doi: 10.1016/j.canlet.2011.12.012

37. Roninson IB, Broude EV, Chang B-D. If not apoptosis, then what? Treatment-induced senescence and mitotic catastrophe in tumor cells. Drug Resist Updat 2001;4:303-13. doi: 10.1054/drup.2001.0213

38. Vakifahmetoglu H, Olsson M, Zhivotovsky B. Death through a tragedy: mitotic catastrophe. Cell Death Differ 2008;15:1153-62. doi: 10.1038/cdd.2008.47

39. Gupte A, Mumper RJ. Elevated copper and oxidative stress in cancer cells as a target for cancer treatment. Cancer Treat Rev 2009;35:32-46. doi: 10.1016/j.ctrv.2008.07.004

40. Dröge W. Free radicals in the physiological control of cell function. Physiol Rev 2002;82:47-95. doi: 10.1152/ physrev.00018.2001

41. Szatrowski TP, Nathan CF. Production of large amounts of hydrogen peroxide by human tumor cells. Cancer Res 1991;51:794-8. PMID: 1846317 


\section{Utjecaj koncentracije i vremena administracije na radiomodulirajuća svojstva undecilprodigozina in vitro}

Undecilprodigiozin pigment (UPP) pokazuje citotoksičnu aktivnost kod različitih tipova tumora. Međutim, njegova učinkovitost u modulaciji staničnog odgovora na ionizirajuće zračenje i dalje je nepoznata. U ovoj studiji ispitani su radiomodulirajući učinci UPP-a in vitro tretiranjem kultura ljudske periferne krvi s UPP-om i ionizirajućim zračenjem. Pri ispitivanju su se koristile dvije vrste tretmana: tretman s UPP-om prije ozračivanja (predtretman) i tretman s UPP-om poslije ozračivanja (posttretman). Djelotvornost UPP-a ispitivana je procjenom njegovih učinaka na zračenjem inducirano formiranje mikronukleusa, staničnu proliferaciju i apoptozu. Redoks-modulirajući učinci UPP-a ispitivani su mjerenjem aktivnosti katalaze i razine malondialdehida kao parametara oksidacijskoga stresa. Rezultati pokazuju da učinci UPP-a na stanični odgovor na ionizirajuće zračenje ovise o njegovoj koncentraciji i vrsti tretmana. Pri niskim koncentracijama UPP pokazuje radioprotekcijski učinak u ozračenim humanim limfocitima, a pri visokim koncentracijama djeluje kao radiosenzibilizator inducirajući ili mitotsku katastrofu ili apoptozu, ovisno o vrsti tretmana. UPP modificira redoks procese u stanici, osobito ako se primjenjuje prije zračenja. Naši rezultati upućuju na značaj daljnjeg ispitivanja UPP-a u cilju njegove primjene za senzibilizaciju tumorskih stanica u terapiji zračenjem inhibicijom puteva koji vode rezistenciji na tretman.

KLJUČNE RIJEČI: apoptoza; ionizirajuće zračenje; mitotska katastrofa; oksidacijski stres; stanična proliferacija 